\title{
Football Fandom, Protest and Democracy
}

Football Fandom, Protest and Democracy offers an in-depth and inside approach to the socio-political history of football in Turkey, where fandom is often revered as part of the national identity, presenting the historical context for football events in the country.

Based on original research, the book explores the complex political processes at play in modern Turkey and deepens our understanding of fandom, fan activism and protest movements, questioning all presuppositions about the society and football fandom in Turkey. In particular, it examines the role of football fans in the pro-democracy Gezi Protests of 2013, the history of football in Turkey, the sociology of the middle classes and the transformation of football in the country.

Interdisciplinary in nature, this book is a valuable resource for scholars and students of sports sociology, popular culture studies, Turkish studies and media studies.

Dağhan Irak is a Lecturer-Researcher at Aix-Marseille University, France teaching Geopolitics, History, Media and Popular Culture. He is also a Research Fellow at the Médialab of Sciences Po Paris, France. He previously worked as a live commentator for Eurosport TV channel. 


\section{Critical Research in Football}

Series Editors:

Pete Millward, Liverpool John Moores University, UK

Jamie Cleland, University of Southern Australia

Dan Parnell, Manchester Metropolitan University, UK

Stacey Pope, Durham University, UK

Paul Widdop, Leeds Beckett University, UK

The Critical Research in Football book series was launched in 2017 to showcase the inter- and multi-disciplinary breadth of debate relating to 'football'. The series defines 'football' as broader than association football, with research on rugby, Gaelic and gridiron codes also featured. Including monographs, edited collections, short books and textbooks, books in the series are written and/or edited by leading experts in the field whilst consciously also affording space to emerging voices in the area, and are designed to appeal to students, postgraduate students and scholars who are interested in the range of disciplines in which critical research in football connects. The series is published in association with the Football Collective, www.footballcollective.org.uk.

Available in this series:

Fan Activism, Protest and Politics

Ultras in Post-Socialist Croatia

Andrew Hodges

Football, Fandom and Consumption

Oliver Brooks

Football Fandom, Protest and Democracy

Supporter Activism in Turkey

Dağhan Irak

For more information about this series, please visit: https:/www.routledge.com/ sport/series/CFSFC 


\section{Football Fandom, Protest and Democracy}

Supporter Activism in Turkey

Dağhan Irak 
First published 2019

by Routledge

2 Park Square, Milton Park, Abingdon, Oxon OXI4 4RN

and by Routledge

52 Vanderbilt Avenue, New York, NY 10017

Routledge is an imprint of the Taylor \& Francis Group, an informa business

(C) 2019 Dağhan Irak

The right of Dağhan Irak to be identified as author of this work has been asserted by him in accordance with sections 77 and 78 of the Copyright, Designs and Patents Act 1988.

All rights reserved. No part of this book may be reprinted or reproduced or utilised in any form or by any electronic, mechanical, or other means, now known or hereafter invented, including photocopying and recording, or in any information storage or retrieval system, without permission in writing from the publishers.

Trademark notice: Product or corporate names may be trademarks or registered trademarks, and are used only for identification and explanation without intent to infringe.

British Library Cataloguing-in-Publication Data

A catalogue record for this book is available from the British Library

Library of Congress Cataloging-in-Publication Data

A catalog record has been requested for this book

ISBN: 978-0-367-2497I-7 (hbk)

ISBN: 978-0-429-28528-8 (ebk)

Typeset in Goudy

by Taylor \& Francis Books 
Annem'e 
This page intentionally left blank 


\section{Contents}

List of figures

viii

Foreword

ix

Acknowledgements

xi

Introduction 1

1 A socio-historical context of football in Turkey 8

2 Football in the Ottoman Empire 20

3 Football in the new Republic of Turkey (1923-1960) 30

4 A new political paradigm (1960-1980) 45

5 Hyper-commodification of football in Turkey 59

6 Football during the AKP period (2002-) 73

7 Gezi matters 91

8 Virtually among the fans 128

$\begin{array}{ll}\text { Conclusion } & 174\end{array}$

$\begin{array}{lr}\text { Index } & 182\end{array}$ 


\section{Figures}

7.1 Political axes and positions represented by political parties in Turkey 


\section{Foreword}

Dr Dağhan Irak, a former sports journalist at Eurosport, connoisseur of football and doctor of sociology at the University of Strasbourg, proposes an original book to the reader, with a dual context of the undying passion for football in Turkey and the mass movements that took the country, especially Istanbul in 2013.

Football fandom is a phenomenon that the sports sociologists have been studying for half a century, initially in its radical form (hooliganism or ultras) in a context of football's transformation in Europe and also the crisis affecting the lower classes from where those fans mostly came. With the 1970s, in all of Europe, professional football came to fruition, was mediatised and the clubs were bureaucratised as the cleavage between executives and the public deepened. In the 1980s, this transformation was accelerated and amplified, firstly in England, and then everywhere else in varying degrees. The increasing security measures in the stadiums, the segmentation of spectators, the emergence of multifunctional stadiums with VIP sections (the prototype being the Amsterdam Arena, opened in 1996), the explosion of transfer expenses and broadcasting revenues were indicators of this massive process. This mutation has had deep repercussions on the football spectators, especially on their more militant groups, the supporters. They were deemed to be undesirable, and were threatened by executives; therefore they took matters into their hands, with actions like protesting against the all-seater stadiums, the ticket prices, the distribution of games into different time slots, security checks and restricting laws. By these actions, they started to oppose the state or the government, directly or indirectly. Football fandom has witnessed a wave of politicisation which has caused a paradigm shift in fandom studies. Dr Irak's book contributes to understanding this shift with a certain twist; he does that in a country where almost all people considers themselves as avid football fans and even express political views through this identity.

Football fans have shown up in different political protests all around the world recently. Two cases were especially remarkable: the revolutionary movement in Egypt which ended the Hosni Mubarak rule in 2011, and the movement against Vikto Yanukovich in Ukraine in February 2014. In 
Turkey, especially in Istanbul which is the centre of gravity of the country, the protesters firstly gathered to protest against an urbanisation project threatening the last remaining recreational areas of the city, and then the autocratic tendencies of the emerging Erdoğan regime. In the international press, the visibility of football supporters was mentioned frequently.

The originality of Dr Irak's research comes from his choice to stray away from the traditional fandom analysis treating the fans 'organically' attached to a club, and to analyse the 'ordinary' independent football fans who attend the games and write a lot about football and other things on the social media. Contrary to the European examples, in Turkey fandom practices are not reserved to the lower classes. As a matter of fact, a lot of supporters in Istanbul come from the middle classes and have a rather high cultural capital. Therefore Dr Irak's research contributes to a new understanding of football fandom in connection with social media and new social movements. The fans appear to be supporting the insurrections with subtle, albeit incoherent, ideological references that cannot be deciphered at first glance.

In his empirical research on the Stambulite football fans, the author brings sociological responses to these social and political phenomena. This type of 'online' fandom constructs a shared identity and also a sense of virtual community that stems from the sports field. The research establishes bonds between the politics and the fandom practised in locations other than the stadium. The book questions the social and political logic behind these fans gathering online, first to express themselves about football, and then to defend an urban and 'modern' lifestyle that revolves around a set of principles that Dr Irak conceptualises as the 'Republican Doxa'.This concept explains the values which make possible the expressions and consensus that he observes through his digital ethnographic work, which enters the working field of an anthropologist or an ethnographer, but with a corporal invisibility that limits the morpho-psychological inference effects of the daily life with carefully crafted research protocols.

In that respect, with its originality and empirical data that it creates, Football Fandom, Protest and Democracy: Supporter Activism in Turkey brings out new information and several untouched avenues for research in relation to football fandom and social movements.

William Gasparini

Sociologist and Professor at the University of Strasbourg Holder of the Jean Monnet Chair in European Sports Sociology (2015-2018) and researcher at the 'Sports and Social Sciences' research lab 


\section{Acknowledgements}

This book is a product of an ongoing journey. Way past my 30s, I decided to end my journalism career to follow my long-sought academic endeavours. Who would have thought that it would become a tumultuous journey through most of which I faced all sorts of obstacles (mainly political ones), and practically live in a suitcase? This book, written in two countries and six cities, includes all the scars and shortcomings of this journey, as well as my coming-of-age as a researcher.

It was a long road, but thankfully, not a lonesome one. Through my journey, I had different people to back me up, admittedly half of whom I managed to annoy somehow. I thank them all, regardless of whether their names are listed below or not.

I would like to thank Bağış Erten and all Eurosport Turkish version crew, who provided me with an honourable exit when I needed to hang up the microphone. I also would like to thank all my viewers and readers through my career as a sports journalist. Even today, some viewers still recognise my voice or a funny remark I made on air. I am thankful for that experience, it was an honour and joy.

I would like to thank Prof. William Gasparini and Prof. Michel Koebel for their tremendous support when I was at the University of Strasbourg as a doctoral candidate. They helped me launch a career in research and teaching, even when I was doubtful that I could write and teach in French, my third language. I would like to thank Prof. Christian Bromberger, Prof. Yasemin İnceoğlu, Prof. Marie-Carmen Garcia, and Dr Samim Akgönül for turning my thesis defence to one of the best academic experiences I have ever had, to this day.

Another thank you is in order for Médialab of Sciences Po Paris, and its director Prof. Dominique Cardon, Collège de France and the PAUSE programme. They welcomed me with open arms when I needed support to continue my career. The PAUSE programme, for researchers in exile from many different countries, makes wonders. If you are an academic working in a French academic institution reading this, please support this programme.

I would also like to thank IDEMEC research lab at Aix-Marseille University, and its director Prof. Benoit Fliche. It is a joy working for you. Also, 
special thanks for providing me with a job under the Mediterranean sun that I had missed dearly.

A very special thanks is much needed for Dr Ece Algan, who appeared as a voluntary mentor in one of the toughest periods of my life, and has never gave up on supporting me ever since.

When you are in uncharted waters, you need friends to survive. Thankfully, I just have the right ones. I would like to thank Can, Melek, Işık, Berna, Ceren, Janet, Deniz, Kerem, Seda, Beril and Gökçe for their endless support, even when I am whiny (aka all the time).

I would not be here writing this without my family. I would like to thank my mother for making me believe in myself. She is the best football fan that I have ever known, of course, except for my grandmother, may she rest in peace. I also thank my sisters for all those years growing up together.

I would like to thank President Recep Tayyip Erdoğan and the regime in Turkey for blacklisting me, just because I signed a petition demanding equal treatment for all the citizens of my country, along with 1,127 other colleagues. Thanks to them, I know now what I can rise above. 


\section{Introduction}

On 31 May 2013, I spent the night crouching on the narrow stairs of a budget hotel facing the European Doctoral College in Strasbourg that would soon become my workplace for the next four years, trying to get my share from the poor Internet connection that would connect me to Istanbul, the city that I was born and grew up in and getting ready to leave. That was my first visit to the European capital of Strasbourg, a surprisingly introvert city despite its historical and actual nature of a crossroads. I was there to showcase my works on the political tendencies of football supporters in Turkey, a subject that I had been interested in for years, as a scholar and a sports journalist. Following a presentation at a conference organised my future research lab, I was hoping to measure up as a doctoral candidate, which would equally mean that my career as a journalist would be over. In my presentation, I drew a basic framework of football fandom in Turkey and why its politicisation would be impossible in the long term, due to the lack of democratic fans' organisations and the feeble civil society in the country in general. On the night of 30 May, at the Gezi Park, in that small recreational space right at the heart of my home town, some hundreds of protesters, including football fans from left-leaning groups, resisted the police and heavy machinery that were trying to force them to make way for an urbanisation project that would eventually turn Gezi into a shopping centre under the guise of the historical Ottoman barracks that were demolished decades before. The project certainly found a sweet spot for Recep Tayyip Erdoğan's populist-Islamist government, as it would serve its agendas of neo-Ottomanism, gentrification and crony-capitalism. The protests were vivid but rickety, the likes of which we had seen during the urbanisation project of the Emek theatre, which eventually demolished the first cinema that I had ever been to for a soulless shopping mall. The Turkish police, as we had witnessed in the Labour Day that year, was getting more and more inclined to use violence; during the Emek protests in April, a friend of mine, a cinema writer, had her hips broken after she was dispersed by the police water cannons. But still, nobody expected that, around $5 \mathrm{am}$, the police would set the tents of the protesters afire, leaving dozens of young, 
inexperienced, non-violent protesters under smoke and circled by fire. Most protesters were independent or members of environmental associations; the members of left-wing parties who were used to facing police violence were not there. Perhaps the only crowd who knew how Turkish police could react were the football supporters, who were quite few at the time. On 31 May, Turkey woke up to a feeling of shock. The country, since the military regime of the 1980s, was quite inured to police violence against left-wing militants; the silent majority of the country had even always supported it. However, such a severe response to hardly political Stambulite kids was unprecedented. The protesters were typical 'okumuş çocuklar', ('educated kids' in Turkish) urban, secular, middle-class youths who had been expected to make great things for the country, since the foundation of the Republic of Turkey in 1923. Meanwhile, the coevals of the protesters, coming from similar upbringings, felt a sudden outrage. That feeling was abrupt, but it did come out of nowhere. Especially after the 2010 Constitution referendum that eliminated all Erdoğan's rivals within the state and practically started the process that would turn Turkey into his one-man rule; the urban, secular, well-educated middle classes started to feel themselves desperate, isolated and ostracised. Erdoğan's attempts to intervene in modern lifestyles and his quest to create 'a pious youth' created an increasing uneasiness among these young people whom you can find in quintessential secular neighbourhoods of the city, such as Beşiktaş, Kadıköy and Beyoğlu. The government, passing a law restricting alcohol sale on 22 May 2013, took its toll on the city's cultural life as the prohibition of sponsorship by alcohol producers cut off the financial lifelines of many events. Moreover, the ever-present fear of Turkey becoming an Islamic state among the 'moderns' was more dominant than ever. The Stambulite secular youth lost Emek, some of its cultural life, and part of liberties directly associated with their lifestyle. The Gezi Park, which most Stambulites had enjoyed without even caring too much about it, somehow became a thread to hang on. And the violent eviction at 5 am was apparently the end of the rope.

At the stairs of the hotel in Strasbourg, I was experiencing a surreal night. I was miles away from home, and what was happening there was something I had never known before. It was like watching a movie taking place in Istanbul - well, a movie that I was trying to stream with the poor hotel connection. But, the feelings that made my generation (and the one after that) take to the streets were not unknown to me. As a journalist, I was feeling myself less and less secure everyday, and my opposition to Turkey's candidacy to host the 2020 Olympics (which was practically a propaganda stunt by Erdogan) had returned as some complaints to my editor-in-chief from higher places. I no longer had the appetite to do my job, and I was eager to get back to the academic world that I had always kept one foot in.

The following two days, which gathered thousands of Stambulites at the streets against the government, was a surprise to me in many ways. As a 
post-1980 child, I had never witnessed or expected any mass demonstration from the Turkish public; seeing hundreds of thousands of people chanting and passing the Bosphorus Bridge was simply unreal to me. Also, I was observing that football fans were becoming a pillar of the protests, the football fans that I just claimed, at the conference, were too apolitical to be organised. Actually, here, I should stop and explain what I mean when I say 'football fans'. Like most sports sociologists, my go-to resource on defining football fans is the famous taxonomy of Giulianotti (2002) that categorises this vast group into four; Supporters, Followers, Fans and Flaneurs, based on their relationship with the club, spatiality, solidarity and identity. However, in Turkey, where everyone claims to be a fan, it is hard to fit anyone into any group. More than $80 \%$ of the supporters in the country follow the Big Three clubs of Istanbul, therefore they have mostly virtual relations in various places. However, identity-wise, they are often nested, and their solidarity is as strong as you can find in a nation, which takes these people into another fandom category. Even though Giulianotti's dichotomy works very well with any other example that I know, in Turkey all the categories are mangled because these three clubs are perceived like micro-nations. These clubs, born simultaneously with the Turkish nation, mimic Turkish nationalism and, like any nationalism, it has imaginary bonds with its members from any walk of life. Therefore, even the relations are often long-distance and relations are virtual, solidarity is strong. In my sample group that I picked among Istanbul-based supporters, again a crossover between different categories occurs; they are on site, therefore they have a grounded identity, strong solidarity and they represent the 'hot' side of fandom. However, they come from the urban middle classes who have been conditioned to be customers since the 1980s, therefore their relationship with their team bounces constantly between supporter and client. This anomaly stems from a core argument of this book; the fan identity, class identity and political identity of urban, secular, middle-class Stambulite fans is interwoven and they function interchangeably. The main subject of this book, the participation of football supporters in the Gezi Protests, is a prime example of this situation. Without giving any spoilers, I will quote the essential question of this book; why do these people from Istanbul wear their football jersey when they go to political protests or a polling stations?

In Turkey, football is so intertwined with other social domains that it cannot be separated. In my 30-something years in Turkey, I had only known a handful of people that I would not identify as a football fan, admittedly most of them in academic circles. It is a country where most people start to read the paper from the sports section. Also, in Turkey, fan groups are not really too organised, they are loose entities around a common identity. You may find tens of thousands of people who would claim they belonged to Çarşı, Ultraslan or Genç Fenerbahçeliler; however, these famous groups, to my mind, do not have more than a few dozen people as a core group. Some 
of these groups are formal associations but, as I will demonstrate later, being a member of an association is exceptional in Turkey, even for religious and regional associations that are more popular than others. The organised fan groups are entities that can grow in a culture of civil society which hardly exists in Turkey. Therefore, when I say 'football fan' I mostly mean ordinary people. Which is why, in the quasi-ethnographic work that will occupy a big portion of this book, I deliberately avoided working with fan groups and chose independent, urban, secular, middle-class football fans. In a political event that gathered over 5 million people in a month, restricting such a dominant identity to a few hundreds of people would effectively miss the mark and quite probably would lead to a selection bias. Gezi was a spontaneous movement that mostly gathered independent people with no political adherence or experience. In order to understand the movement, one should analyse such people.

The story of football and its fandom in Turkey cannot be told without its relationship with politics. Football in this country was born into politics and has never been separated from it ever since. Without knowing the role of football in the emergence of modern Turkey, it is impossible to understand why certain things happen in football in Turkey. For example, in a country of 80 million more than $80 \%$ of the population are estimated to support three Stambulite teams: Beşiktaş, Galatasaray and Fenerbahçe. Without knowing these clubs' roles in the Turkish national struggle, we cannot understand why they have always been treated as if they were national teams. Therefore, I ask for your patience, since the story that leads up to the Gezi Park starts at the beginning of the 20th century. We should first explain why football is interwoven with nationalism, modernity or secularism, and then we will be able to explain the reactions of football fans before, during and after the events. That is why I will start telling the story from the very beginning, when football clubs in Turkey did not even exist and football was a game played between the British merchants and their non-Muslim counterparts in the port cities of the Ottoman Empire. Football in Turkey and the structure of clubs have a unique relationship with Turkish nationalism. Not only were the clubs born into it, they also took it as a model to create their own micro-nationalisms. The Stambulite clubs are nations within a nation, and the identities they engendered are inseparable from the core principles of the Republic - the Republic that was entrusted to the urban, secular middle classes of Turkey by its founding fathers, and has been dismantled today by Recep Tayyip Erdoğan. The early history of football in Turkey actually sheds a light on why football has found itself in the middle of this cultural battle that reached a climax in Gezi.

Thus, football in Turkey has always been political, but it has always been proudly apolitical. Even though it may seem as a clear paradox, it completely overlaps everything Turkey was built upon. The country has been constituted upon a gigantic state that dictates everything in the whole political 
field, and a dwarf civil society where feeble democracy takes place. Therefore, politics around predefined principles (that I will call the 'Republican Doxa') occupies a huge place, but the remaining, democratic political debate is confined to fringes and is often met with hostility. In other words, as long as you do not cross the acceptable lines you can be as political as you want; however, crossing the lines could easily make you an outcast in the eyes of the state and society. The Erdoğan era is a period when these lines are renegotiated and vastly redesigned. This transformation lies at the heart of the current political tension. Football environments (stadiums and any other public place that fandom takes place), which have traditionally been secular spaces, have been prime examples of the public repercussions that this transformation created. Football fans that have very rarely crossed the accepted political lines found themselves as outcasts, even enemies of the new regime. Their apoliticality became political. Before analysing how they reacted through my ethnographic work, I aim to explain the Republican Doxa and those lines that used to define acceptable and unacceptable politics. This part will require a background knowledge of the core issues that constitute the political fault lines of the society in Turkey, such as religion, secularism, the Kurdish question or the Armenian genocide. I am more than willing to explain why all these and more fall within the Republican Doxa, and how these will reappear as recurring themes during my ethnographic work.

I used digital ethnography as the principal method in this study. For three and a half years, I worked with 60 football supporters who individually and independently joined the protests. That sample obviously brings out a certain question; is it possible to conduct an ethnography of people who do not know each other and do not act interconnectedly? My answer to this question is a certain 'yes', since it is a common identity and shared values that gathered millions of otherwise disparate people in Gezi. In a setting where the lack of political organisation and experience, as well as an overt hostility against political entities, dominated, the answer to why and how millions of people acted spontaneously but harmoniously in this unprecedented social event lies in the common set of values that were engraved on the perception of Turkish urban, secular, middle classes. My work takes a sample of football supporters that were brought to the streets by the Republican Doxa. Therefore, it is impossible not to consider these individuals as a group. Digital ethnography makes it possible to work on such a disjointed but unified group. The method also opens the door to an additional depth of analysis that would be otherwise impossible. Thanks to this method, we are able to access the expressions of the sample group before the Gezi Protests to create a timeline that starts one year before the events to two and a half years after. This presents a unique opportunity to detect continuities and ruptures in political expressions and positions. To my knowledge, among the hundreds of works about Gezi, this work is the only one that analyses the participants before the events. 
For this research, I used Twitter messages posted by the sample group. Since the Iran elections in 2009, Twitter has proven to be an important political tool, especially during mass protests. In Turkey, Facebook is the most popular social media platform, as in most countries; however, the semi-private structure of that platform makes it practically impossible to see all the actors in a network setting. Twitter, on the other hand, is an agora where all users are interconnected (unless their accounts are locked, which is a very rare practice); users may be relatively protected by anonymity, and the tool itself is designed to be used in mobile environments. As the quintessential social network, Twitter appeared as a platform of political communication even before the Gezi Protests. However, in a country where digital divide and unequally distributed cultural capital have had an important effect, a tardily localised tool such as Twitter was first dominated by certain groups who were more tech-savvy and connected to the outside world. Before presenting my research, I would like to explain why Twitter emerged as a platform vastly dominated by the secular opposition, to the extent that Tayyip Erdoğan called it 'the worst menace to society' and vowed to eradicate it. Also, the cultural battle in Turkey is actually a struggle between the cultural capital and the social capital owners in the country; in other words, the educated few and the organised masses. It is a battle between diversity and majoritarianism. Technology plays an essential role in this battle, and the Stambulite football fandom has also been nurtured by its technological capital for decades. Therefore, it is crucial to explain the complex ties between technology, modern middle classes and football fandom. Even though they seem irrelevant, hopefully the reader will realise that they are surprisingly interlacing. As a matter fact, this relationship, which is admittedly a tough case to crack, is what makes the case of football fandom in Turkey unique.

For the quasi-ethnographic part of my work, I chose two axes; thematic and periodic. In the thematic part of the analysis, I will present my findings in relation to the core elements of the Republican Doxa. In the periodic part, I divided my research into periods that start and end with important political events, such as elections or political scandals. The first axis aims to show political positions that the sample group members take, while the second attempts to understand when the sample expresses itself politically. The final objective of the work is equally twofold; firstly, I try to understand to what extent the sample group is motivated by the restoration of the Republican Doxa while making a political statement, and whether their positions changed with the Gezi. Secondly, I try to detect whether their political expressions are part of an enduring political stance, or mere reactions to political events that somehow concern them. And finally, there is one other important objective of this research. The Gezi Protests took place in 2013, not only as an unprecedented political event but also one without a successor. It has been five years since Gezi, and society in Turkey has 
gradually become a society with no political reactions. Indeed, the climate of fear created by the Erdoğan regime plays an immense role in this situation. However, I believe that explaining all the silence with this sole fact would mean overlooking deeper reasons.

This book is not a football book. It is a book about the society in Turkey that takes football as a lead. As I said, almost everybody in Turkey is a football fan. It is perhaps the only remaining common interest that all the people are still invested in. Therefore, I firmly believe that trying to understand Turkey through football fandom is not a crazy idea. Obviously, this book only covers a specific layer of the society in the country; the urban, secular, middle classes that are often referred as the 'moderns'. In a country with millions of football fans, this sport may help understanding several other parts of the society. Mine is an exploratory attempt to show different possibilities, regarding subject and methodology. In many ways, it is a mere drop in the ocean. I certainly hope it would lead to many others. 


\section{Notes}

\section{Chapter 2}

1 Through this chapter, I will often make references to the late football historian Mehmet Ali Gökaçtı's influential book Bizim İçin Oyna, of which I had the chance to be the co-editor with Tanil Bora. Unfortunately, the author is no longer with us and this valuable work has only been published in Turkish.

2 The name was originally chosen in English.

\section{Chapter 3}

1 By 1938, Prime Minister Şükrü Saracoğlu was Fenerbahçe chairman and Beşiktaş was presided over by one of the major ideologues of the Republican People's Party (Cumhuriyet Halk Partisi - CHP), Recep Peker. Galatasaray, which did not have a high-rank CHP member president at the time, was suffering from the breakaway of Güneş which contained many high-ranking officials of the party.

\section{Chapter 5}

1 Adana Demirspor (Adana), Bursaspor (Bursa) and Çukurova İdman Yurdu (Mersin) were the sole three provincial clubs in the Second Division of 1963-64 the season.

2 Faruk Ilgaz, interview with the author, 18 October 2007, Istanbul, Turkey.

3 This law has still been in effect, with a couple of changes.

\section{Chapter 7}

1 As might be expected, these anti-AKP iftars were met by police violence, while famous journalists like Aslı Aydıntaşbaş of Milliyet and Nazlı Ilıcak of Sabah were actively contributing to the AKP's PR efforts, just metres away. It is ironic that both journalists, along with hundreds of others, lost their jobs soon after for not being sufficiently pro-AKP. Ilicak was later condemned to life sentence, accused of 'being part of the coup d'etat attempt in 2016'.

\section{Chapter 8}

1 'Birlik, beraberlik içinde olmak'

2 The emblematic chic street of the Kadıköy district where Fenerbahçe fans often meet. 
3 Çapulcu means 'looter' in Turkish; it was an expression first used by Tayyip Erdoğan against Gezi participants, later appropriated by them.

4 In Turkish, 'to be French to something' is the equivalent of 'it's Greek to me' in English. The Galatasaray supporters use this expression, also to mock with Fenerbahçe fans' claims that Galatasaray is not Turkish enough, but French, because the Galatasaray High School, the graduates of which founded the club, is the biggest French-teaching institution outside France.

5 Atam means 'my ancestor' in Turkish and is almost exclusively used for Mustafa Kemal Atatürk.

6 The Fenerbahçe supporters often call their club the 'Fenerbahçe Republic'.

7 Even though Erdoğan gave up liberal ideas in the 2010s, he continued to use the word 'Türkiyeli', which he also used during his victory speech after the presidential elections in 2014.

8 Apo is the nickname for Abdullah Öcalan.

9 The Menemen incident is an Islamist revolt in 1930, in which a young military officer was decapitated by the rebels. This incident triggered a military operation and heavy prison sentences against the convicts. 


\section{Bibliography}

Beşiktaş Postası. 29 October 2009, 'Kartal Yuvası'nda Çarşı telaşı'. Available online at www.besiktaspostasi.com/kartal-yuvasinda-carsi-telasi.htm [1 December 2018].

Bora, Tanıl. 'Dur Tarih, Vur Türkiye'. In Roman Horak, Wolfgang Reiter and Tanıl Bora (eds), Futbol ve Kültürü. Istanbul: İletişim, 2004, 221-240.

Bostancıoğlu, Adnan. 'Taraftar ve Solcu Olmak'. In Roman Horak, Wolfgang Reiter and Tanıl Bora (eds), Futbol ve Kültürü. Istanbul: İletişim, 2004, 241-250.

Karakışla, Yavuz Selim. 'The Emergence of the Ottoman Industrial Working Class'. In Workers and the Working Class in the Ottoman Empire and the Turkish Republic: 1839-1950. LondonandNew York: Tauris Academic Studies, 1995.

Nash, Rex. 'Contestation in Modern English Professional Football: The Independent Supporters Association Movement'. International Review for the Sociology of Sport 35, no. 4(2000): 465-486.

Türk Futbol Tarihi 1-2. Istanbul: Türkiye Futbol Federasyonu, 2013.

Yüce, Mehmet. Osmanlı Melekleri, 1st ed. Istanbul: İletişim, 2014.

Alan, Gülbadi. 'Protestan Amerikan Misyonerleri, Anadolu'daki Rumlar ve Pontus Meselesi’. Erciyes Üniversitesi Sosyal Bilimler Enstitüsü Dergisi 10 (2001): 186-208.

Dağlaroğlu, Rüştü. Fenerbahçe Spor Kulübü Tarihi: 1907-1957. Istanbul: n.p, 1957.

Ertuğrul, Cem. 'General Harington Kupası'. Available online at www.fenerbahce.org/ kurumsal/detay.asp?ContentID=3561 [1 December 2018].

Gökaçtı, Mehmet Ali. Bizim İçin Oyna: Türkiye'de Futbol ve Siyaset. Istanbul: İletişim, 2008.

Güneş, Günver. 'Osmanlı İmparatorluğu'nda 19. Yüzyıldan 20. Yüzyıla ... İzmir'de Futbol'. Toplumsal Tarih 142 (October 2005): 68-77.

Millas, Herkül. Yunan Ulusunun Doğuşu. Istanbul: İletişim, 1994.

Solomonidis, Christos. Tis Smyrnis. Athens: np, 1957.

Türk Futbol Tarihi 1-2. Istanbul: Türkiye Futbol Federasyonu, 2013.

Akın, Yiğit. Master's thesis, Boğaziçi University Atatürk Institute, 2003.

Akın, Yiğit. Gürbüz ve Yavuz Evlatlar. Istanbul: İletişim, 2004.

Akşam, 17 September 1945-1931 May 1949.

Atabeyoğlu, Cem. 1453-1991 Türk Spor Tarihi Ansiklopedisi. Istanbul: Fotospor, 1991.

Atabeyoğlu, Cem. Interview by author. Digital audio recording. Istanbul, Turkey, 19 March, 2007.

Dağlaroğlu, Rüştü. Fenerbahçe Spor Kulübü Tarihi: 1907-1957. Istanbul: n.p, 1957.

Gökaçtı, Mehmet Ali. Bizim İçin Oyna: Türkiye'de Futbol ve Siyaset. Istanbul: İletişim, 2008. 
Kızılyürek, Niyazi. 'Birinci Cumhuriyet'ten Yeni Kıbrıs'a'. In Masis Kürkçügil (ed.), Kibrls: Dün ve Bugün. Istanbul: Ithaki, 2003.

Milliyet, 14 June 1955.

Pyta, Wolfram. 'German Football: A Cultural History'. In Alan Tomlinson and Christopher Young (eds), German Football: History, Culture, Society. London and New York: Routledge, 2006, 1-22.

Zürcher, Eric Jan. Turkey: A Modern History. London: I. B.Tauris, 2005.

Ahmad, Feroz. 'The 1983 Elections'. MERIP Reports, March/April 1984. Available [online] at www.jstor.org/stable/3011796 [22 February 2019].

Bayar, Ali. 'The Developmental State and Economic Policy in Turkey'. Third World Quarterly 17, no. 4 (1996): 773-786.

Bozarslan, Hamit. 'Political Aspects of the Kurdish Problem in Contemporary Turkey'. In Philip K. KreyenbroekandStefan Sperl (eds), The Kurds: a Contemporary Overview. London: Routledge, 1991, 76-103.

Cankaya, Özden. 'Türk Televizyonun Program Yapısı'. Author's own publication. n.d.

Dağı, İhsan D. 'Democratic Transition in Turkey, 1980-1983: The Impact of European Diplomacy'. Middle Eastern Studies 32, no. 2 (1996): 124-141.

Hasgüler, Mehmet. Kibrıs'ta Enosis ve Taksim Politikalarının Sonu. Istanbul: İletişim, 2002. İnsel, Ahmet. 'CHP Nedir?' 6 September 2008. Available online at www.birikimder gisi.com/guncel-yazilar/652/chp-nedir [1 December 2018].

InselAhmet. 'The AKP and Normalizing Democracy in Turkey'. South Atlantic Quarterly 102, no. 2/3 (2003): 293-308.

Milliyet, 13 March 1971-1931 July 1990.

ÖndülHüsnü and Yavuz Önen. 'Basına ve Kamuoyuna'. Available online at www.ihd.org. tr/index.php?option $=$ com_content $\&$ view $=$ article $\& i d=32$ : basina-ve-kamuoyuna $\&$ catid=30:ortak-baslamalar\&Itemid $=80$ [12 December 2009].

Pamuk, Şevket. 'Political Economy of Industrialization in Turkey'. MERIP Reports, 1981.

Paul, Jim. 'The Coup'. MERIP Reports, no. 4, 1993. Available [online] at www.jstor. org/stable/3011658 [22 February 2019].

Zürcher, Eric Jan. Turkey: A Modern History. London: I.B.Tauris, 2005.

Akın, Yiğit. 'Not Just a Game: The Kayseri vs. Sivas Football Disaster'. Soccer \&ु Society 5, no. 2 (2004), 219-232.

Bora, Tan1. 'Dur Tarih, Vur Türkiye'. In Roman Horak, Wolfgang Reiter and Tanıl Bora (eds), Futbol ve Kültürü. Istanbul: İletişim, 2004, 221-240.

Devecioğlu, Sebahattin. 'Türkiye Futbol Federasyonu'nun Özerkliği'. Gazi Beden Eğitimi ve Spor Bilimleri Dergisi 8, no. 3 (2003), 49-58.

Gökaçtı, Mehmet Ali. Bizim İçin Oyna: Türkiye'de Futbol ve Siyaset. Istanbul: İletişim, 2008.

Milliyet, 20 June 1970 - 1 February 1985.

Star, 7 April 2000.

Buğra, Ayşe, and Osman Savaşkan. New Capitalism in Turkey: The Relationship between Politics, Religion and Business. Cheltenham, UK; Northampton, MA: Edward Elgar, 2014.

Çavdar, Ayşe. 'Building, Marketing and Living in an Islamic Gated Community: Novel Configurations of Class and Religion in Istanbul: Building, Marketing and Living in an Islamic Gated Community'. International Journal of Urban and Regional Research 40, no. 3 (2016): 507-523.

Futbol Aktiiel. TV broadcast, NTV, 18 January 2017. 
Güney, Emir. 'Supporter Ownership in Turkish Football'. In Borja García and Jinming Zheng (eds), Football and Supporter Activism in Europe. Cham: Springer International Publishing, 2017, 257-276. Milliyet, 19 February 2002.

TBMM Investigation Report 10/63. Available online at www.tbmm.gov.tr/sirasayi/ donem22/yi101/ss956.pdf [22 February 2019].

TBMM Parliamentary Minutes, 23rd term, 5th year, 85th session. Available online at www.tbmm.gov.tr/develop/owa/tutanak_sd.birlesim_baslangic?P4=20907\&P5=B\& PAGE1=63\&PAGE2=\&web_user_id=17388821 [22 February 2019].

Wacquant, Loï J. D. 'From ruling class to field of power: An interview with Pierre Bourdieu on La Noblesse d'Etat'. Theory Culture and Society 10 (1993): 19-44.

Akçam, Taner. From Empire to Republic: Turkish Nationalism and the Armenian Genocide. London: Zed Books, 2004.

Aouragh, Miriyam. 'Social Media, Mediation and the Arab Revolutions'. TripleC (Cognition, Communication, Co-Operation): Open Access Journal for a Global Sustainable Information Society 10, no. 2 (2012).

Atak, Kivanc. 'D'Istanbul à Rio de Janeiro, des soulèvements de classe?' Revue internationale et stratégique 93, no. 1 (2014): 81-89.

Atay, Tayfun. 'The Clash of "Nations" in Turkey: Reflections on the Gezi Park Incident'. Insight Turkey 15, no. 3 (2013): 39-44.

Attali, Jacques, and others. 'Rapport de La Commission Pour La Libération de La Croissance Française’. XO Éditions, La Documentation Française 16 (2008): 47-52.

Aytaç, Selenay. 'Multilingual Information Retrieval on the Internet: A Case Study of Turkish Users'. The International Information EF Library Review 37, no. 4 (2005): 275-284.

Barbera, Pablo, and Megan Metzger. 'A Breakout Role for Twitter? The Role of Social Media in the Turkish Protests'. Social Media and Political Participation Lab Data Report, 2013.

Ben Youssef, Adel. 'Les quatre dimensions de la fracture numérique'. Réseaux 127-128, no. 5 (2004): 181.

Bennett, W. L. 'New Media Power'. In Nick Couldry and J. Curran (eds), Contesting Media Power: Alternative Media in a Networked World. Lanham, MD: Rowman \& Littlefield, 2003, 17-37.

Berkes, Niyazi. The Development of Secularism in Turkey. Montreal: McGill University Press, 1964/1998.

Best, Steven, and Douglas Kellner. 'Contemporary Youth and the Postmodern Adventure'. Review of Education, Pedagogy, and Cultural Studies 25, no. 2 (2003): 75-93.

Bianet. 12 Günde 52 Liseden Bildiri. 2016. Available online at http://bianet.org/bianet/ genclik/175771-12-gunde-48-liseden-bildiri [1 December 2018].

Bilgiç, Esra Ercan, and Zehra Kafkaslı. Gencim, ozgurlukcuyum, ne istiyorum? \#Direngeziparki anketi sonuc raporu. Istanbul: Istanbul Bilgi Üniversitesi Yayınları, 2013.

Bourdieu, Pierre. 'The Forms of Capital (1986)'. Cultural Theory: An Anthology 1 (2011): 81-93.

Bourdieu, Pierre. La Distinction: Critique Sociale Du Jugement. Paris: Minuit, 1979.

Brecht, Bertolt. 'Radio as a Means of Communication: A Talk on the Function of Radio'. Screen 20, no. 3-4 (1930/1979): 24-28.

Brooks, Sam, Paul Donovan and Clint Rumble. 'Developing Nations, the Digital Divide and Research Databases'. Serials Review 31, no. 4 (2005): 270-278.

Bruns, Axel, Katrin Weller and Stephen Harrington. 'Twitter and Sports: Football Fandom in Emerging and Established Markets'. Twitter and Society 89 (2014): 263-280. 
Burns, Alex, and Ben Eltham. 'Twitter Free Iran: An Evaluation of Twitter's Role in Public Diplomacy and Information Operations in Iran's 2009 Election Crisis'. Communications Policy \& Research Forum 2009, 19-20 November 2009, University of Technology, Sydney.

Çarkoğlu, Ali, and Melvin J. Hinich. 'A Spatial Analysis of Turkish Party Preferences'. Electoral Studies 25, no. 2 (2006): 369-392.

Çarkoğlu, Ali. 'www.oypusulasi.org web sitesinden elde edilen verilerden elde edilen birkaç ön sonuç’. 2011. Available online at https:/pr.ku.edu.tr/sites/pr.ku.edu.tr/ files/Basin_Duyurusu.pdf [1 December 2018].

Cerisier, Jean-François. 'Acculturation Numérique et Médiation Instrumentale. Le Cas Des Adolescents Français'. Université de Poitiers, 2011.

Çiftçi, Kemal. 'The Kemalist Hegemony in Turkey and the Justice and Development Party (AKP) as an ?Other'. L'Europe en Formation 367, no. 1 (2013): 143.

Couldry, Nick, and James Curran, eds. Contesting Media Power: Alternative Media in a Networked World. Critical Media Studies. Lanham, MD: Rowman \& Littlefield, 2003.

Deringil, Selim. 'Legitimacy Structures in the Ottoman State: The Reign of Abdülhamid II (1876-1909)'. International Journal of Middle East Studies 23, no. 3 (1991): 345-359.

Doğuç, Seçil. 'Bir Hapishane İsyanı Olarak Gezi Deneyimi'. In Emrah Göker and Vefa Saygin Ögütle (eds), Gezi Ve Sosyoloji: Nesneyle Yüzleşmek, Nesneyi Kurmak. Istanbul: Ayrınt1, 2014, 158-169.

Dorronsoro, Gilles, and Olivier Grojean. 'Engagement Militant et Phénomènes de Radicalisation Chez Les Kurdes de Turquie'. European Journal of Turkish Studies. Social Sciences on Contemporary Turkey, 2009.

Dorsey, James M. 'Soccer: A Middle East and North African Battlefield'. 2011. Available online at https://papers.ssrn.com/sol3/papers.cfm?abstract_id=1955513.

Downing, John. 'The Independent Media Center Movement and the Anarchist Socialist Tradition'. In Nick Couldry and J. Curran (eds), Contesting Media Power: Alternative Media in a Networked World. Lanham, MD: Rowman \& Littlefield, 2003, 243-257.

Draelants, Hugues, and Magali Ballatore. 'Capital culturel et reproduction scolaire. Un bilan critique'. Revue française de pédagogie. Recherches en éducation 186 (2014): 115-142.

Durakbaşa, Ayşe. 'Gezi Direnişi ve Türkiye'de Toplumsal/Siyasal Tahayyül Ufkumuzun Açılması için Sosyolojik İzlekler'. In Emrah Göker and Vefa Saygın Ögütle (eds), Gezi Ve Sosyoloji: Nesneyle Yüzleşmek, Nesneyi Kurmak. Istanbul: Ayrınt1, (2014): 191-202.

Eltantawy, Nahed, and Julie B. Wiest. 'The Arab Spring| Social Media in the Egyptian Revolution: Reconsidering Resource Mobilization Theory'. International Journal of Communication 5 (2011): 18.

European Commission. Turkey Report, 2011-2013.

Fuchs, Christian. 'Information and Communication Technologies and Society a Contribution to the Critique of the Political Economy of the Internet'. European Journal of Communication 24, no. 1 (2009): 69-87.

Ghorashi, Halleh, and Kees Boersma. 'The "Iranian Diaspora" and the New Media: From Political Action to Humanitarian Help'. Development and Change 40, no. 4 (2009): 667-691.

Gögüs, Idil, and Sabine Mannitz. 'The World Culture Entered Turkey'. 2016. Available online at http://hsfk.de/fileadmin/user_upload/prif139.pdf [1 December 2018]. 
Göktürk, Duygun, Gökçe Güvercin and Onur Seçkin. 'The New Stream of Trade Unionism: Egitim-Bir-Sen in Turkey'. In Kemal İnal and Güliz Akkaymak (eds), Neoliberal Transformation of Education in Turkey: Political and Ideological Analysis of Educational Reforms in the Age of the AKP. New York: Palgrave Macmillan, 2012, $109-121$.

Göle, Nilüfer. 'Gezi-Anatomy of a Public Square Movement'. Insight Turkey 15, no. 3 (2013): 7-14.

Gür, Emre. 'Erdoğan's Historic Achievement: Provoking the Most Heterogeneous Opposition Movement in the World'. L'Europe en Formation 367, no. 1 (2013): 135.

Hacıyakupoğlu, Gulizar, and Weiyu Zhang. 'Social Media and Trust during the Gezi Protests in Turkey'. Journal of Computer-Mediated Communication 20, no. 4 (2015): 450-466.

Hardt, Michael, and Antonio Negri. 'The Fight for "Real Democracy" at the Heart of Occupy Wall Street'. Foreign Affairs 11 (2011).

Hargittai, Eszter. 'Digital $\mathrm{Na}(\mathrm{t})$ Ives? Variation in Internet Skills and Uses among Members of the "Net Generation"”. Sociological Inquiry 80, no. 1 (2010): 92-113.

Howard, Philip N., and Muzammil M. Hussain. 'The Role of Digital Media'. Journal of Democracy 22, no. 3 (2011): 35-48.

'Hükümete yedi talep ilettiler'. Habertürk. Available online at www.haberturk.com/ gundem/haber/850186-hukumete-7-talep-ilettiler [1 December 2018].

Insight Radar. Gezi Olayları Sosyal Medya Yansimalar ve Analizi 29 Mayı - 17 Haziran. 2013.

Jenkins, Gareth H. 'Between Fact and Fantasy: Turkey's Ergenekon Investigation'. Central Asia-Caucasus Institute, Paul H. Nitze School of Advanced International Studies, 2009.

Jenkins, Gareth. 'A House Divided against Itself: The Deteriorating State of Media Freedom in Turkey'. Central Asia-Caucasus Institute Silk Road Studies Program, 2012. Available online at 01fe00c.netsolhost.com/images/Turkey_12_Feb_6_A_house_ divided_against_itself_.pdf [22 February 2019].

Juris, Jeffrey S. 'Reflections on \#Occupy Everywhere: Social Media, Public Space, and Emerging Logics of Aggregation: Reflections on \#Occupy Everywhere'. American Ethnologist 39, no. 2 (2012): 259-279.

Kahn, Richard, and Douglas Kellner. 'New Media and Internet Activism: From the "Battle of Seattle" to Blogging'. New Media Eु Society 6, no. 1 (2004): 87-95.

Kahn, Richard, and Douglas Kellner. 'Oppositional Politics and the Internet: A Critical/Reconstructive Approach’. Cultural Politics 1, no. 1 (2005): 75-100.

Karadağ, Meltem. 'Gezi Parkı Direnişi ve Orta Sınıf'. In Emrah Göker and Vefa Saygin Ögütle (eds), Gezi Ve Sosyoloji: Nesneyle Yüzleşmek, Nesneyi Kurmak. Istanbul: Ayrint1, 2014, 186-190.

Kévorkian, Raymond H. The Armenian Genocide: A Complete History. London; New York: I. B.Tauris, 2011.

Keyder, Çağlar. 'Çağlar Keyder: Law of the Father'. LRB Blog (blog). Available online at www.lrb.co.uk/blog/2013/06/19/caglar-keyder/law-of-the-father/ [1 December 2018].

Kucukcan, Talip. 'Sacralization of the State and Secular Nationalism: Foundations of Civil Religion in Turkey'. Geo. Wash. Int'l L. Rev. 41 (2009): 963.

Kurban, Dilek, and Ceren Sözeri. İktidarın çarkında medya: Türkiye'de medya bağımsızlı̆̆1 ve özgürlügü önündeki siyasi, yasal ve ekonomik engeller. TESEV, 2012. 
Kurtuluş, Hatice. 'Kente Hak Mücadelesinde Sokağın İşgali, Sınıflar ve Gezi Parkı Direnişi'. In Emrah Göker and Vefa Saygın Ögütle (eds), Gezi Ve Sosyoloji: Nesneyle Yüzleşmek, Nesneyi Kurmak. Istanbul: Ayrıntı, 2014, 261-275.

Kuymulu, Mehmet Bariş. 'Reclaiming the Right to the City: Reflections on the Urban Uprisings in Turkey'. City 17, no. 3 (2013): 274-278.

Langman, Lauren. 'From Virtual Public Spheres to Global Justice: A Critical Theory of Internetworked Social Movements'. Sociological Theory 23, no. 1 (2005): 42-74.

Leighton, Wayne A. 'Broadband Deployment and the Digital Divide: A Primer'. A Cato Institute Policy Analysis. No. 410, 7 August 2001.

McConnaughey, James W., Timothy Sloan and Cynthia Ann Nila. Falling through the Net: A Survey of the' Have Nots' in Rural and Urban America. National Telecommunications and Information Administration, Department of Commerce, 1995. Available online at www.ntia.doc.gov/files/ntia/publications/falling-through-net-ii.pdf [22 February 2019].

Mardin, Serif. Türkiye'de Toplum ve Siyaset (Butun Eserleri) (Turkish Edition). Istanbul: İletişim Yayınları, 1990.

Massicard, Élise. 'La Judiciarisation Contrastée de La Question Alévie'. Revue Française de Science Politique 64, no. 4 (2014): 711-733.

Meyen, Michael, Senta Pfaff-Rüdiger, Kathrin Dudenhöffer and Julia Huss. 'The Internet in Everyday Life: A Typology of Internet Users'. Media, Culture $\mathcal{E}$ Society 32, no. 5 (2010): 873-882.

Miller, Daniel, Elisabetta Costa, Nell Haynes, Tom McDonald, Razvan Nicolescu, Jolynna Sinanan, Juliano Spyer, Shriram Venkatraman and Xinyuan Wang. How the World Changed Social Media. London: UCL press, 2016.

Morozov, Evgeny. 'Iran: Downside to the "Twitter Revolution"”. Dissent 56, no. 4 (2009): 10-14.

Murdock, Deroy. Digital Divide? What Digital Divide. Washington, DC: Cato Institute, 2000.

Navaro-Yashin, Yael. 'The Market for Identities: Secularism, Islamism, Commodities'. In Deniz Kandiyoti and Ayșe Saktanber, (eds), Fragments of Culture: The Everyday of Modern Turkey. London: I.B.Tauris, 2002, 221-253.

Novak, Thomas P. and Donna L. Hoffman. 'Bridging the Racial Divide on the Internet'. Science 280, no. 5362 (1998): 390-392.

OECD. Syndicats: Taux de syndicalisation, Statistiques de l'OCDE sur l'emploi et le marché du travail. 2014. Available online at https://doi.org/10.1787/data-00371-fr [22 February 2019].

Özatalay, Cem. 'Gezi Direnişi: Antikapitalist mi, Alter-Kapitalist mi?'. In Emrah Göker and Vefa Saygın Ögütle (eds), Gezi Ve Sosyoloji: Nesneyle Yüzleşmek, Nesneyi Kurmak. Istanbul: Ayrint1, (2014): 170-185.

Pamuk, Şevket. 'Globalization, Industrialization and Changing Politics in Turkey'. New Perspectives on Turkey 38 (2008): 267-273.

Pérouse, Jean-François. La Turquie en marche: Les grandes mutations depuis 1980. Paris: La Martinière, 2004.

Polat, Burak, Cemile Tokgöz Bakıroğlu, and Mira Elif Demirhan Sayın. 'Hactivism in Turkey: The Case of Redhack'. Mediterranean Journal of Social Sciences1 October 2013.

PromoQube. Facebook Türkiye Istatistikleri. Available online at www.slideshare. net/marketallica/facebook-trkiye-statistikleri [1 December 2018]. 
Qualman, Erik. Socialnomics: How Social Media Transforms the Way We Live and Do Business. Hoboken, NJ: John Wiley \& Sons, 2010.

Rojas, Viviana, Debasmita Roychowdhury, Ozlem Okur, Joe Straubhaar, and Yinan Estrada-Ortiz. 'Beyond Access: Cultural Capital and the Roots of the Digital Divide'. In Erik Bucy and John Newhagen (eds), Media Access: Social and Psychological Dimensions of New Technology Use. Hillsdale, NJ: Erlbaum, 2004, 107-130.

Saada, Julien. 'Révoltes Dans Le Monde Arabe: Une Révolution Facebook?' Montréal, Observatoire Sur Le Moyen-Orient et l'Afrique Du Nord de La Chaire Raoul Dandurand, 2011. Available online at dandurand.uqam.ca/wp-content/uploads/ sites/3/2016/04/Chronique_OMAN_fev2011.pdf [22 February 2019].

Selwyn, N. 'Reconsidering Political and Popular Understandings of the Digital Divide'. New Media Eु Society 6, no. 3 (2004): 341-362.

Sınır, Şahin. 'Gezi, Kürtler ve Kanaatlerin Kıyısındaki Kırılgan Politik Repertuarlar'. In Emrah Göker and Vefa Saygın Ögütle (eds), Gezi Ve Sosyoloji: Nesneyle Yüzleşmek, Nesneyi Kurmak. Istanbul: Ayrınt1, 2014: 203-220.

Stanley, Laura D. 'Beyond Access: Psychosocial Barriers to Computer Literacy Special Issue: ICTs and Community Networking'. The Information Society 19, no. 5 (2003): $407-416$.

Steyaert, Jan. 'Inequality and the Digital Divide: Myths and Realities'. In S. Hick and J. McNutt (eds), Advocacy, Activism and the internet. Chicago, IL: Lyceum Press, 2002, 199-211.

Suny, Ronald Grigor. 'Truth in Telling: Reconciling Realities in the Genocide of the Ottoman Armenians'. The American Historical Review114, no. 4 (2009): 930-946.

'Taksim Dayanışması Ortak Deklarasyonu'. Toplumsol (27 April 2012). Available online at www.toplumsol.org/taksim-dayanismasi-ortak-deklarasyonu/ [1 December 2018].

Tankeu, Robertine. 'Fracture Numérique de Genre Au Cameroun: Quelle Ampleur?' ENDA/ANAÎS, 2005. Available online at villagesuisseong.org/pdf/Rapport $\% 20$ fina 1\%20FNG\%20au\%20Cameroun\%20V1.pdf [22 February 2019].

Tayla, Alican. 'L'AKP et l'autoritarisme en Turquie : une rupture illusoire'. Confluences Méditerranée 83, no. 4 (2012): 87.

Thierer, Adam. 'How Free Computers Are Filling the Digital Divide'. Backgrounder 1361 (2000).

Tondeur, J., I. Sinnaeve, M. van Houtte and J. van Braak. 'ICT as Cultural Capital: The Relationship between Socioeconomic Status and the Computer-Use Profile of Young People'. New Media EF Society 13, no. 1 (2011): 151-168.

Tuğal, Cihan. 'The Islamic Making of a Capitalist Habitus'. In David Brady (ed.), Comparing European Workers Part A. Emerald Group Publishing, 2011, 85-112.

Tuğal, Cihan. “'Resistance Everywhere”: The Gezi Revolt in Global Perspective'. New Perspectives on Turkey 49 (2013): 157-172.

Türkmen, Füsun. 'The European Union and Democratization in Turkey: The Role of the Elites'. Human Rights Quarterly30, no. 1 (2008): 146-163.

Ünsald1, Levent. 'Les conceptions du développement en Turquie'. Revue Tiers Monde204, no. 4 (2010): 165.

Yavuz, Onur. 'Kahrolsun Bazı Veriler'. In Emrah Göker and Vefa Saygın Ögütle (eds), Gezi Ve Sosyoloji: Nesneyle Yüzleşmek, Nesneyi Kurmak. Istanbul: Ayrınt1, 2014: 99-123.

Yörük, Erdem. 'The Long Summer of Turkey: The Gezi Uprising and Its Historical Roots'. South Atlantic Quarterly, 113, 2 (2014): 419-426. 
Zillien, Nicole, and Eszter Hargittai. 'Digital Distinction: Status-Specific Types of Internet Usage'. Social Science Quarterly 90, no. 2 (2009): 274-291.

Zürcher, Eric Jan. Turkey: A Modern History. London: I.B.Tauris, 2005.

Akdeniz, Eylem, and Emrah Göker. 'The Historical "Stickiness" of Nationalism inside Turkey's Political Field'. Turkish Studies 12, no. 3 (2011): 309-340.

Irak, Dağhan. 'Turkish Football, Match-Fixing and the Fan's Media: A Case Study of Fenerbahçe Fans.' In Katherine Dashper, Thomas Fletcher and Nicola McCullough (eds), Sports Events, Society and Culture. London: Routledge, 2014, 133-146.

Irak, Dağhan, and Jean-François Polo. 'Turkey'. In Jean-Michel De Waele, Suzan Gibril, Ekaterina Gloriozova and Ramón Spaaij (eds), The Palgrave International Handbook of Football and Politics. Cham: Springer International Publishing, 2018, 659-676.

Kirişçi, Kemal. 'The Transformation of Turkish Foreign Policy: The Rise of the Trading State'. New Perspectives on Turkey 40 (2009): 29-56.

Libération. 16 May 2014. Available online at https:/www.liberation.fr/planete/2014/05/16/ espece-de-sperme-d-israel-erdogan-accuse-d-antisemitisme_1018945 [22 February 2019].

Navaro-Yashin, Yael. Faces of the State: Secularism and Public Life in Turkey. Princeton, NJ: Princeton University Press, 2002.

Star, 13 June 2013.

The Foundation of Human Rights of Turkey Report, 2016. Available online at http:// tihv.org.tr/wp-content/uploads/2016/03/T\%C4\%BOHV-Soka $\% C 4 \% 9 F a-\% C 3 \% 87 \%$ C4\%B1kma-Yasaklar\%C4\%B1-Bilgi-Notu-18-Mart-2016.pdf [22 February 2019].

The Guardian, 21 March 2014.

Tombuş, H. Ertuğ. 'Reluctant Democratization: The Case of the Justice and Development Party in Turkey'. Constellations 20, no. 2 (2013): 312-327.

Uğurlu, Esra. 'Nourrir la métropole autrement: une entrée par Istanbul.' In RIODD 2016. Available online at https://hal.archives-ouvertes.fr/hal-01349974. 